\title{
PENGARUH PEMBANGUNAN JALAN TOL MEDAN-TEBING TINGGI TERHADAP USAHA MIKRO KECIL DAN MENENGAH
}

\section{THE EFFECT OF HIGH-MEDIUM AND MEDIUM MICRO TOLL DEVELOPMENT}

\author{
1Januardin Manullang, ${ }^{2 H o t t u a ~ S a m o s i r ~}$ \\ 1Univeristas Prima Indonesia - Medan \\ 2Universitas Prima Indonesia - Medan \\ Email: januardin.manullang@gmail.com
}

\begin{abstract}
ABSTRAK
Pembangunan jalan tol sangat penting bagi kemjuan dan perkembangan suatu wilayah atau daerah, pembangunan jalan tol mendorong percepatan penyaluran dan pengiriman barang dan manusia. Adapun rangkuman permasalahan yang dihadapi para usaha mikro kecil dan menengah yang ada dipasar bengkel adalah 1 . Berkurangnya angkutan pribadi dan umum untuk singgah di pasar bengkel. 2 Menurunnya pendapatan sejak adanya jalan tol medan-tebing tinggi. 3 Sudah banyaknya para pedagang tutup karena onzet berkurang drastis.Tujuan penelitiaan ini untuk mengetahui pengaruh apa saja yang timbul dari dilakukannya pembangunan jalan tol medan-tebing tinggi terhadap umkm dikawasan bengkel. Metode penelitian yang dipakai adalah metode penelitian kualitatif teknik pengumpulan data dilakukan secara trianggulasi. 1) Dampak yang dihasilkan oleh pembangunan jalan tol Medan-Tebing Tingi sangat terasa pada Usaha Mikro, Kecil dan Menengah Pasar Bengkel. 2)Faktor-faktor yang dialami oleh Usaha Mikro, Kecil dan Menengah pasar bengkel adalah Faktor Kurangnya pendapatan, faktor tenaga kerja yang tidak ada lagi, faktor pendapatran daerah yang semakin menurun.
\end{abstract}

Kata Kunci : Jalan Tol, UMKM, Kualitatif

\begin{abstract}
The construction of toll roads is very important for the progress and development of a region or region, the construction of toll roads encourages the acceleration of the distribution and delivery of goods and people. The summary of the problems faced by small and medium micro businesses in the workshop market is 1. Decreased private and public transportation to stop at the workshop market. 2 The decline in income since the existence of high-cliff-field toll roads. 3 The number of traders has been closed because onzet has drastically reduced. The purpose of this research is to find out what influences arise from the construction of high-cliff-field toll roads on the roads in the workshop area. The research method used is a qualitative research method of data collection techniques conducted in triangulation. 1) The impact of the construction of the Medan-Tebing Tingi toll road is very pronounced in the Micro, Small and Medium Enterprises Market Workshop. 2) Factors experienced by the Micro, Small and Medium Enterprises in the workshop market are Factors of Lack of income, labor factors that no longer exist, regional factor factors are declining.
\end{abstract}

Keywords : Highway, UMKM, Qualitative 


\section{PENDAHULUAN}

Pembangunan jalan tol sangat penting bagi kemjuan dan perkembangan suatu wilayah atau daerah, pembangunan jalan tol mendorong percepatan penyaluran dan pengiriman barang dan manusia. Pembangunan jalan tol sedikit banyaknya berdampak terhadap pembangunan wilayah yang dilintasi, pembangunan jalan tol yang baik tidak akan merugikan wilayah atau kawasan yang dilintasi. Dampak yang sering terjadi dalam pembangunan jalan tol adalah berkurangnya wilayah perkebunana atau persawahan, tidak dimanfaatkannya masyarakat setempat dalam pembentukan umkm dalam hal ini pembangunan rest area.

Penelitian yang dilakukan oleh Setiawan (2014:1) jenis resiko dan tingkat resiko pada tiap tahapan proyek untuk proyek dengan system kontrak gabungan lump sum dan unit price juga tergantung pada jenis pekerjaan, lokasi proyek, kompleksitas pekerjaan dan tingkat kemampuan (pengalaman) kontraktor, bukan hanya pada tipe kontrak yang digunakan dalam pembangunan jalan tol cisumdawu.

"Peran masyarakat dalam pembangunan nasional, utama dalam pembangunan ekonomi adalah Usaha Mikro, Kecil, dan Menengah (UMKM). Posisi Usaha Mikro, Kecil, dan Memengah (UMKM) dalam perekonomian nasional memiliki peran yang penting dan strategis. Konsidisi tersebut sangat memungkinkan karena eksistensi UMKM cukup dominan dalam perekonomian Indonesia, dengan alas an jumlah industry yang besar dan terdapat dalam setiap sector ekonomi, potensi yang besar dalam penyerapan tenaga kerja, dan kontribusi UMKM dalam pembentukan Produk Domestik Bruto (PDB) sangat dominan" (Sofyan 2017: 33)

Program aksi pengentasan kemiskinan melalui pemberdayaan UMKM yang telah dicanangkan Presiden Yudhoyono pada tanggal 26 Februari 2005, terdapat empat jenis kegiatan pokok yang akan dilakukan yaitu, 1. Penumbuhan iklim usaha yang kondusif, 2. Pengembangan system pendukung usaha, 3. Pengembangan wirausaha dan keungulan kompetitif, serta 4. Pemberdayaan usaha skala mikro. Yang semuanya bertujuan untuk menentaskan kemiskinan melalui UMKM. (Supriyanto 2006:1)

Usaha Mikro Kecil dan Menengah mampu bertahan secara makro ekonomi mampu meyangga perekonomian nasional. Hal itu dapat kita lihat dari masa-masa krisis yang terjadi di negeri ini, baik krisis ekonomi tahun 1998 dan 2008. Usaha Mikro Kecil dan Menengah mampu menciptakan lapangan kerja bagi masyarakat banyak dan mampu menjadi alternatif solusi dari masalah kemiskinan. Pasar Bengkel merupakan sebuah pusat jajanan atau Pusat Oleh-oleh yang ada di kabupaten Serdang Bedagai. Pasar Bengkel berada di kawasan Jalan Lintas Sumatera (Jalinsum), tepatnya di Desa Bengkel, Kecamatan Perbaungan, Serdang Bedagai, Sumatera Utara. Pasar Bengkel juga terkenal dengan sebutan Pasar Dodol. Pasar bengkel telah ada sekitar puluhan tahun yang lalu.

Pasar bengkel memiliki potensi usaha dodol yang cukup bagus. Dodol telah menjadi ciri khas daerah ini sehingga permintaannya akan tetap ada.. Penjualan dodol yang setiap tahunnya meningkat membuat makanan ini memiliki prospek yang cerah untuk dikembangakan karena bahan baku untuk pembuatannya tersedia secara lokal. Penjualan dodol tersebut semakin meningkat sejak adanya pemekaran kabupaten pada tahun 2004 dari Deli Serdang menjadi Serdang Bedagai. Para usahawan juga mengikuti pelatihan mengelola usaha 5 dodol. Pasar bengkel tidak hanya menjual dodol saja, tetapi para pengusaha juga menghiasi tokonya dengan jajanan yang beraneka ragam dan minuman botol yang membuat suasana toko menarik untuk dilihat. 
Dari hasil wawancara yang dilakukan oleh peneliti pada beberapa pengusaha yang ada di pasar bengkel sebelum adanya jalan tol Medan-Tebing tinggi, hasil penjualan dodol rata-rata mencapai $20 \mathrm{~kg}$ perharinya. Dengan harga dodol Rp 40.000/kg. Keripik rata-rata 50 bungkus perhari dengan harga Rp. 20.000/3 bungkus sedangkan penjualan dari jam 7 magrib sampai jam 2 subuh sebanyak Rp. 2.000 .000 dari berbagai produk. Sedangkan sesudah adanya jalan tol medan-tebingtinggi penjualan dodol rata-rata penjualan $3 \mathrm{~kg}$ paling banyak dan penjualan kripik hanya rata-rata 3 bungkus per hari dan penjualan semua produk dari jam 7 magrib sampai jam 2 subuh hanya sebesar Rp. 60.000. dan sebanyak kurang lebih 30 tokoh sudah tutup atau gulung tikar.

Adapun rangkuman permasalahan yang dihadapi para usaha mikro kecil dan menengah yang ada dipasar bengkel adalah :

1. Berkurangnya angkutan pribadi dan umum untuk singgah di pasar bengkel.

2. Menurunnya pendapatan sejak adanya jalan tol medan-tebing tinggi.

3. Sudah banyaknya para pedagang tutup karena onzet berkurang drastis.

Tujuan penelitiaan ini untuk mengetahui pengaruh apa saja yang timbul dari dilakukannya pembangunan jalan tol medan-tebing tinggi terhadap umkm dikawasan bengkel.

\section{LANDASAN TEORI}

\section{Teori Usaha Mikro Kecil dan Menengah}

Menurut Tambunan (2012: 11) UMKM adalah unit usaha produktif yang berdiri sendiri, yang dilakukan oleh orang perorangan atau badan usaha di semua sector ekonomi. Pada prinsipnya, pembedaan antara UMI, UK, UM dan UB umumnya didasarkan pada nilai asset awal (tidak termasuk tanah dan bangunan), omset rata-rata per tahun, atau jumlah pekerja tetap.

Sesuai dengan Undang- Undang Nomor 20 Tahun 2008 tentang Usaha Mikro, Kecil dan Menengah (UMKM):

1) Usaha Mikro adalah usaha produktif milik orang perorangan dan/atau badan usaha perorangan yang memenuhi kriteria Usaha Mikro sebagaimana diatur dalam UndangUndang ini.

2) Usaha Kecil adalah usaha ekonomi produktif yang berdiri sendiri, yang dilakukan oleh orang perorangan atau badan usaha yang bukan merupakan anak perusahaan atau bukan cabang perusahaan yang dimiliki, dikuasai, atau menjadi bagian baik langsung maupun tidak langsung dari usaha menengah atau usaha besar yang memenuhi kriteria Usaha Kecil sebagaimana dimaksud dalam Undang-Undang ini.

3) Usaha Menengah adalah usaha ekonomi produktif yang berdiri sendiri, yang dilakukan oleh orang perseorangan atau badan usaha yang bukan merupakan anak perusahaan atau cabang perusahaan yang dimiliki, dikuasai, atau menjadi bagian baik langsung maupun tidak langsung dengan Usaha Kecil atau usaha besar dengan jumlah kekayaan bersih atau hasil penjualan tahunan sebagaimana diatur dalam Undang-Undang ini.

Menurut Undang-Undang No. 20 Tahun 2008, pada pasal 6 dijelaskan kriteria-kriteria yang tepat mengenai UMKM.

1. Kriteria Usaha Mikro, ada dua kriteria usaha ini yakni:

a. Memiliki kekayaan bersih maksimal Rp 50.000.000,00 (lima puluh juta rupiah) tidak termasuk tanah dan bangunan tempat usaha; atau 
b. Memiliki hasil penjualan tahunan paling banyak Rp $300.000 .000,00$ (tiga ratus juta rupiah).

2. Kriteria Usaha Kecil. Kriteria usaha ini meliputi:

a. Memiliki kekayaan bersih lebih dari Rp 50.000.000,00 (lima puluh juta rupiah) tidak termasuk tanah dan bangunan tempat usaha; atau

b. Memiliki hasil penjualan tahunan lebih dari Rp $300.000 .000,00$ (tiga ratus juta rupiah) sampai dengan paling banyak Rp 2.500.000.000,00 (dua miliar lima ratus juta rupiah).

3. Kriteria Usaha Menengah. Ada dua kriteria Usaha Menengah, yaitu:

a. Memiliki kekayaan bersih lebih dari Rp 500.000 .000 (lima ratus juta rupiah) sampai dengan paling banyak Rp 10.000.000.000,00 (sepuluh miliar rupiah) tidak termasuk tanah dan bangunan tempat usaha; atau

b. Memiliki hasil penjualan tahunan lebih dari Rp 2.500.000.000,00 (dua miliar lima ratus juta rupiah) sampai dengan paling banyak Rp50.000.000.000,00 (lima puluh miliar rupiah).

Karakteristik Usaha Kecil adalah tidak adanya pembagian tugas yang jelas antara bidang administrasi dan operasi, rendahnya akses industri kecil terhadap lembaga kredit, belum dipunyainya status badan hukum dan hammpir semuanya bergerak pada usaha industri makanan, minuman dna tembakau. Kemudian dalam pengembangan usaha kecil dan koperasi sebagai basis ekonomi kerakyatan merupakan salah satu langkah strategik yang perlu ditindaklanjutin (Kuncoro dalam Endang dkk, 2018). Strategi pemberdayaan yang tepat adalah meliputi : 1) Aspek managerial meliputi peningkatan produktivitas, pemasaran dan pengembangan sumber daya manusia, 2) Aspek pemodalan, 3) Mengembangan pola kemitraan

Mengembangkan sentra industry kecil dan pembinaan untuk bidang usaha dan daerah tertentu lewat kelompok usaha bersama dan koperasi industry kecil dan kerajinan.Beberapa metoda dalam Penyataan Standar Akuntansi Keuangan (PSAK) terhadap penerapan prinsip konservatisma; a) PSAK No.13 mengenai akuntansi untuk investasi, menyatakan bahwa biaya dapat ditentukan berdasarkan FIFO, rata-rata tertimbang, atau LIFO. Nilai pasar dapat ditentukan portofolio agregat, dalam total atau menurut urutan kategori investasi, atau investasi individual, secara konsisten, b) PSAK No.14 memberikan kebijakan kepada manajemen, bahwa manajemen perusahaan dapat mencatat dan menghitung biaya persediaan dengan menggunakan salah satu metode dengan menggunakan rumus FIFO, LIFO dan rata- rata tertimbang. c) PSAK No.16 mengijinkan manajemen untuk mengestimasi masa manfaat suatu aset tetap berdasarkan pertimbangan yang berasal dari pengalaman perusahaan ketika menggunakan aktiva serupa. Aset tetap dan penyusutan yang mengatur estimasi masa manfaat suatu aktiva tetap.

\section{METODOLOGI PENELITIAN}

Metode penelitian yang dipakai adalah metode penelitian kualitatif, metode penelitian kualitatif adalah sebagai metode penelitian yang berlandaskan pada filsafat postpositivisme, digunakan untuk meneliti pada kondisi objek yang alamiah, dimana peneliti sebagai instrument kunci. Sugiyono (2016:16), teknik pengumpulan data dilakukan secara trianggulasi (gabungan) baik itu dengan cara kuesioner, wawancara dan studi pustaka, analysis data bersifat induktif/kualitatif. 


\section{HASIL DAN PEMBAHASAN}

\section{Hasil Penelitian}

Pembangunan jalan tol merupakan salah satu solusi dari pendistribusian baik barang dan manusia dengan cara mudah dan efektif dari sisi waktu dan jarak. Pembangunan jalan tol merupakan salah satu solusi yang ditawarkan oleh pemerintah sekarang ini untuk mempercepat pertumbuhan di suatu daerah dan melakukan perataan pembangunan di setiap daerah. Pembangunan jalan tol akan memberikan kontribusi yang negatif ketika pembangunan itu dilakukan dengan cara tidak mementingkan beberapa unsur, baik itu dari unsur masyarakat maupun lingkungan. Dampak negatif ini akan membuat pertumbuhan di beberapa pihak akan terhambat, sehingga sedikit banyaknya akan mempengaruhi pembangunan secara keseluruhan. Terdapat dua faktor yang mempengaruhi kinerja UMKM yaitu 1. Faktor internal yaitu akses permodalan, kemampuan berwirausaha, SDM, pemasaran, rencana bisnis, pengetahuan keuangan dan 2. Faktor eksternal yaitu dukungan pemerintah, legalitas, jaringan social, akses kepada informasi, teknologi, pembinaan. (Sudiarta : 2014)

Dalam penelitian ini, objek penelitian diambil secara random atau acak, dimana para responden merupakan pemilik took yang ada di sekitaran pasar bengkel, ada pun banyaknya responden dalam penelitian ini adalah sebanyak 36 toko yang masih aktif berjualan. Karena berdasarkan studi di lapangan, ternyata sudah banyak yang tutup toko yang tutup di karenakan dampak dari pembangunan jalan tol Medan- Tebing Tinggi.

\section{Faktor Pendapatan}

Penilaian akan dilakukan dengan melihat pertumbuhan pendapatan dari toko-toko yang ada di sekitaran pasar bengkel. Penilaian pendapatan terdiri dari 4 kategori, yaitu :

1. Kategori I memiliki pendapatan Rp. 50.000 .000 sampai Rp. 40.000 .000 .

2. Kategori II memiliki pendapatan Rp. 39.000 .000 sampai Rp. 30.000 .000 .

3. Kategori III memiliki pendapatan Rp. 29.000 .000 sampai Rp. 20.000 .000

4. Kategori IV memiliki pendapatan Rp. 19.000 .000 sampai Rp. 0

\section{Grafik 1. Pendapatan Sebeum ada Jalan Tol}

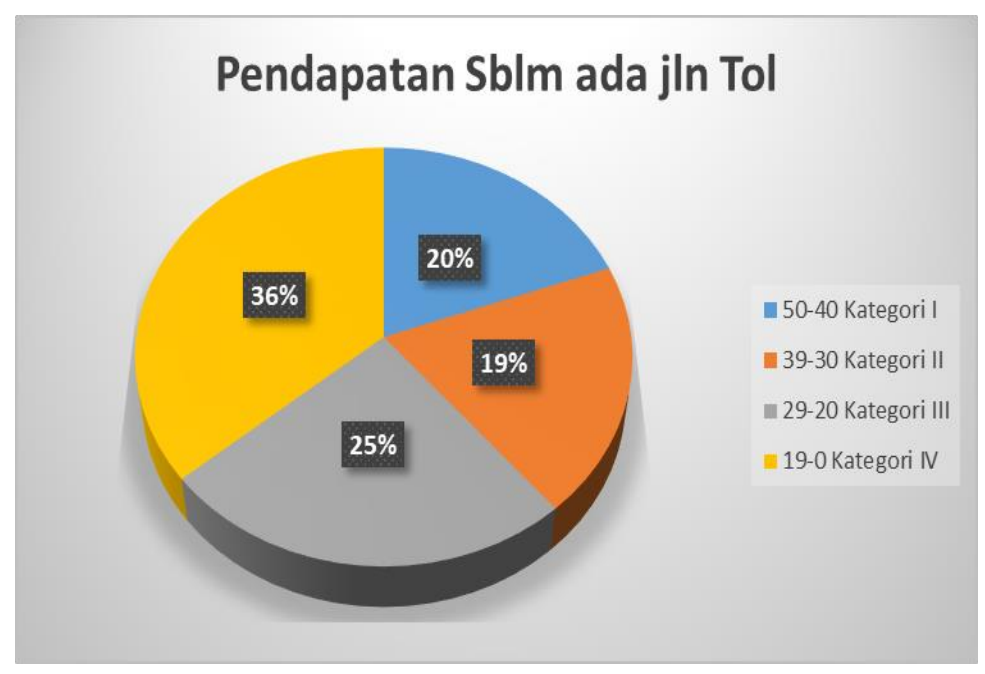

Sumber : data olah, 2019 
Dari grafik 1, dapat dilihat bahwa pendapatan dari 36 toko yang ada di sekitaran pasar bengkel sebelum ada jalan tol yaitu kategori I ada sebesar $20 \%$ atau sebanyak 7 toko, sedangkan kategori II sebesar $19 \%$ atau sebanyak 7 toko, dan kategori III sebesar $25 \%$ atau sebanyak 9 toko, kemudian kategori IV sebesar $36 \%$ atau sebanyak 13 toko.

\section{Grafik 2. Pendapatan setelah ada Jalan Tol}

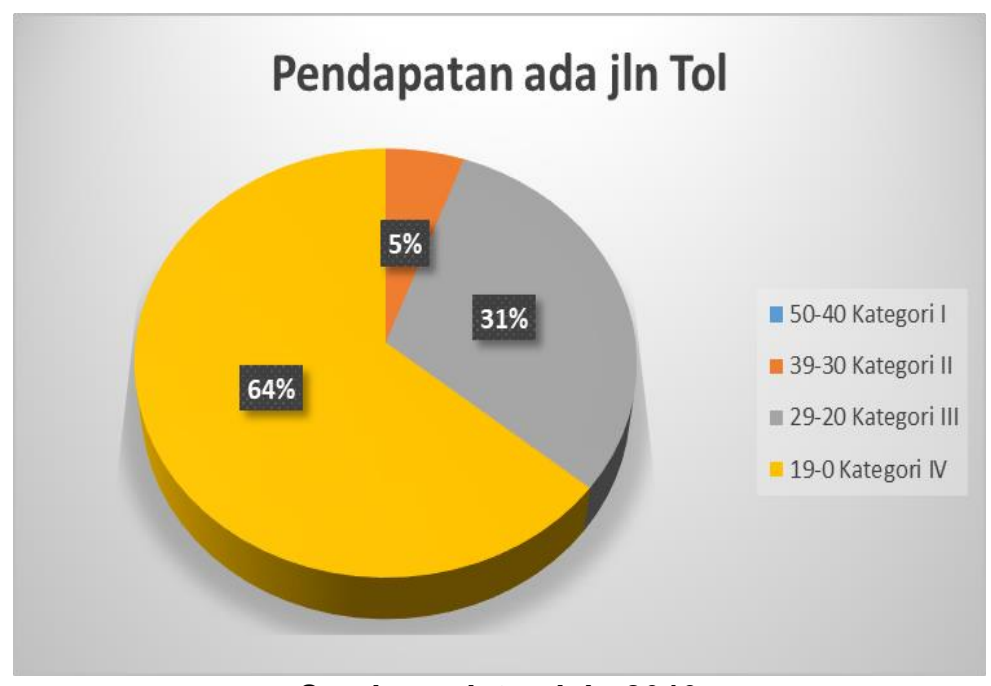

Sumber : data olah, 2019

Dari grafik 2 dapat dilihat bahwa pendapatan dari 36 toko yang ada di sekitaran pasar bengkel sesudah ada jalan tol yaitu kategori I ada sebesar $0 \%$ atau tidak ada toko yang mencapai kategori 1 pendapatannya, sedangkan kategori II sebesar $5 \%$ atau sebanyak 2 toko, dan kategori III sebesar $31 \%$ atau sebanyak 11 toko, kemudian kategori IV sebesar $64 \%$ atau sebanyak 23 toko.

Wanita (2015: 250) perkembangan Usaha Mikro, Kecil dan Menengah dapat dilihat dari aspek pendapatan dari hasil penjualan (omzetnya), penambahan jenis atau jumlah dagangan/produk, dan penggunaan tenaga kerja dalam kegiatan Usaha Mikro Kecil dan Menengah itu.

\section{Faktor Tenaga Kerja}

"Pembangunan masyarakat atau sumber daya manusia merupakan hal yang utama setelah pembangunan infrastruktur, karena bagaimana mungkin masyarakatnya mampu menerima pembangunan dan mau mendorong pembangunan yang ada di daerahnya jika tidak ada perubahan pola pikir dari masyarakat setempat"(Situmorang 2019: 63)

Tenaga kerja merupakan salah satu unsur utama dalam sebuah usaha dalam menjamin terlaksananya suatu proses usaha itu, pemerintah selalu berusaha untuk menguranggi pengangguran dengan membuka lapangan kerja di setiap lini bisnis usaha. Peran pemerintah itu dapat dirasakan baik secara langsung dan secara tidak langsung, dampak dari pembangunan jalan tol Medan-Tebing Tinggi sangat berpengaruh sekali kepada penguranggan dan penambahan pengangguran, hal itu dengan dapat dilihat dari hasil observasi lapangan : 


\section{Grafik 1. \\ Jumlah Karyawan dari 36 Toko}

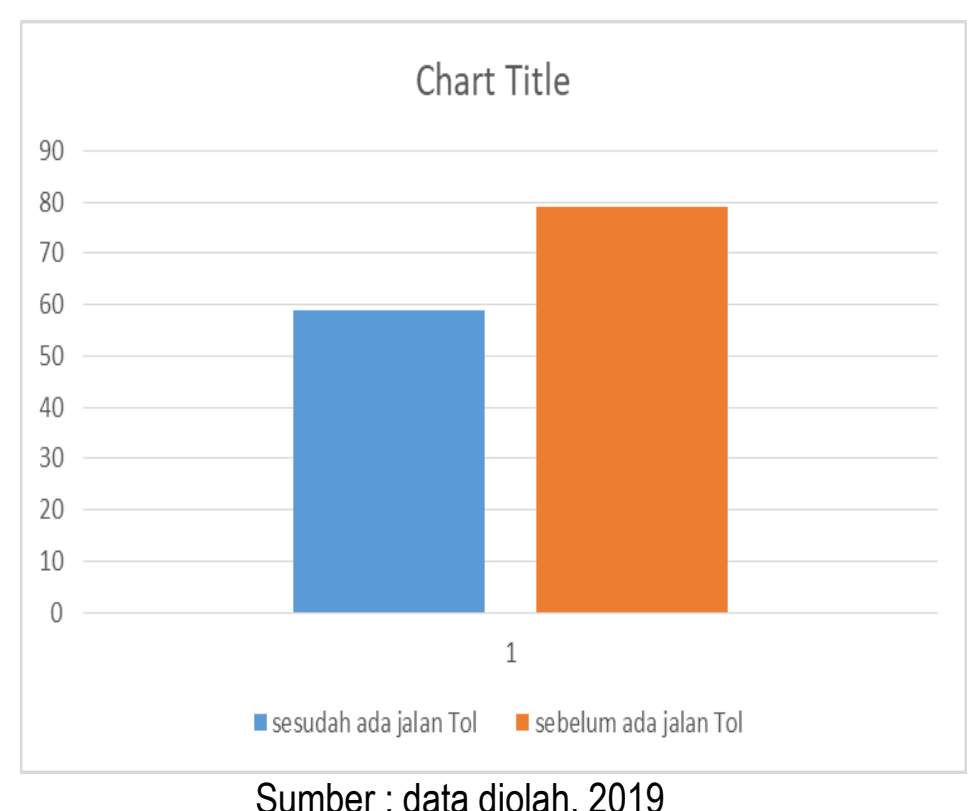

Dari grafik 1, dapat kita lihat bagaimana pertumbuhan jumlah karyawan atau tenaga kerja yang ada di 36 toko yang ada di sekitaran pasar bengkel, pada saat belum ada jalan tol ada sebanyak 79 orang karyawan sedangkan sesudah ada jalan tol terjadi pengurangan totalnya menjadi 59 orang. dampak dari pembangunan jalan tol sangat terasa dengan terjadinya pengurangan tenaga kerja yang ada di toko-toko tersebut.

\section{Faktor Pendapat Asli Daerah}

Pendapatan Asli Daerah, selanjutnya disebut PAD adalah pendapatan yang diperoleh daerah yang dipungut berdasarkan Peraturan Daerah sesuai dengan peraturan perundang undangan (UU Nomor 33 Tahun 2004 Pasal 1, ayat 18). Sumber Pendapatan Asli Daerah, diperoleh dari :

a. Pajak Daerah

Pajak daerah merupakan salah satu komponen pendapatan asli daerah yang diperoleh dari orang pribadi atau badan. Mardiasmo (2009), menyatakan pajak daerah adalah iuran wajib yang dilakukan oleh orang pribadi atau badan kepada daerah tanpa imbalan langsung yang seimbang, yang dapat dipaksakan berdasarkan peraturan perundang-undangan yang berlaku, yang digunakan untuk membiayai penyelenggaraan pemerintah daerah dan pembangunan daerah.

b. Retribusi Daerah

Retribusi daerah, yang selanjutnya disebut retribusi, adalah pungutan Daerah sebagai pembayaran atas jasa atau pemberian izin tertentu yang khusus disediakan dan/atau diberikan oleh Pemerintah Daerah untuk kepentingan orang pribadi atau badan.

c. Hasil pengelolaan kekayaan daerah yang dipisahkan

Kontribusi tersebut dapat berupa deviden yang dibayarkan kepada daerah atau juga dengan memanfaatkan kekayaan daerah seperti penyewaan tanah dan bangunan daerah yang dapat mendatangkan tambahan bagi penerimaan daerah. Jenis pendapatan yang tergolong dari hasil pengelolaan kekayaan daerah yang dipisahkan ini antara lain, bagian laba, deviden. 
d. Lain-lain PAD yang sah

Yang termasuk dalam penerimaan lain-lain $P A D$ yang sah antara lain : hasil penjualan barang milik daerah, penjualan barang-barang bekas, cicilan kendaraan bermotor, cicilan rumah dinas, penerimaan atas kekayaan daerah, sumbangan pihak ketiga, penerimaan jasa giro (kas daerah) dan lain-lain. Rumusnya menghitung pendapatan asli daerah adalah Pajak Daerah + Retribusi Daerah + Hasil Pengelolaan Kekayaan Daerah yang Dipisahkan + Lain - lain PAD yang Sah.

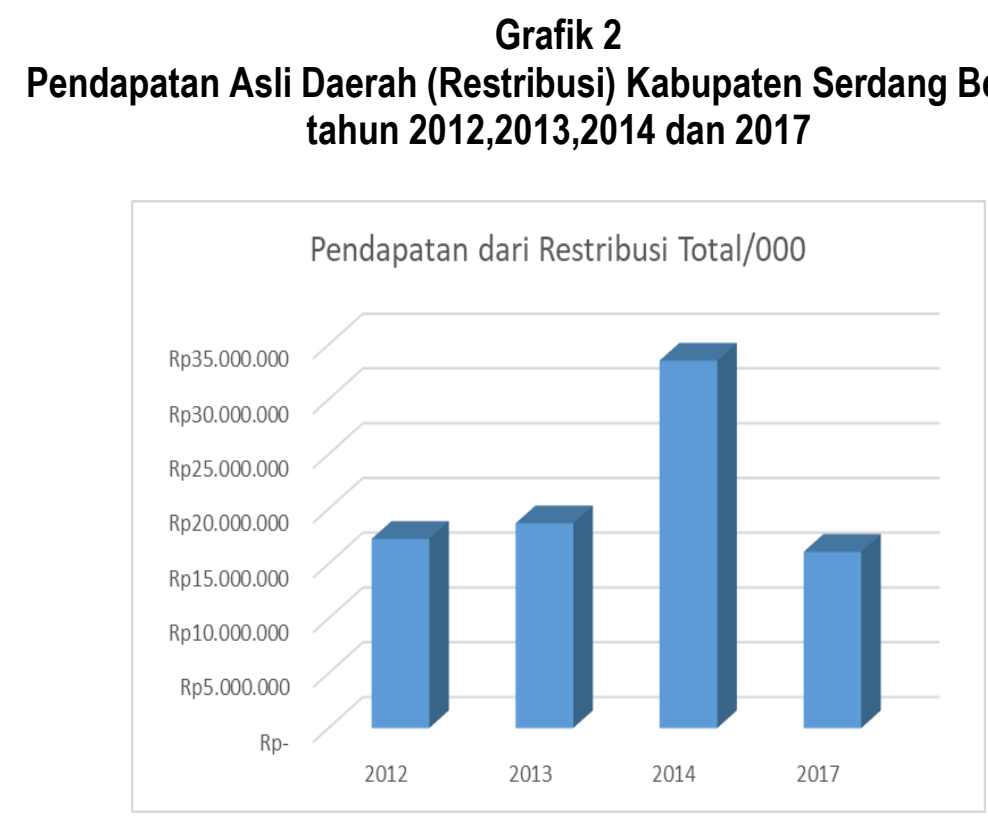

Sumber : BPS, 2019

Jalan tol ruas Parbarakan-Sei Rampah sepanjang 41,7 kilometer diresmikan oleh Presiden Joko Widodo pada 13 Oktober 2017. Maka sejak awal tahun 2017 para pengusaha UMKM di sekitaran pasar bengkel sudah merasakan dampak yang terjadi. Yaitu pengurangan pelanggan yang singgah untuk membeli jajanan, minuman dan lainnya. Dari tabel 6.3 dapat kita lihat pendapatan asli daerah kabupaten serdang bedagai sejak tahun 2012 sampai 2014 terjadi peningkatan sebesar Rp17.273.636.000 pada tahun 2012 dan pada tahun 2013 sebesar Rp18.698.686.000 dan pada tahun 2014 sebesar Rp33.547.554.000. namum sejak pembangunan jalan tol ruas Parbaraka-Sei Rampah terjadi penurunan signifikan yaitu sebesar Rp.16.087.440.000 hal ini dikarenakan turunnya pendapatan distribusi dari UMKM pasar bengkel.

Berdasarkan kuesioner terbuka yang disebar, maka di dapat juga unsur positif dari pembangunan jalan tol Medan- Tebing Tinggi. Ada pun unsur positif itu meliputi :

1. Polusi udara yang berkurang

2. Tidak ada kemacetan

3. Terbukanya peluang penjualan secara online

4. Pesaing berkurang karena banyak yang tutup.

Pembangunan jalan tol Medan-Tebing Tinggi sangat memiliki dampak yang baik dan tidak baik bagi masyarakat yang tinggal di sekitaran jalan lintas sumatera kabupaten serdang berdagai. Pembangunan ini akan mempermudah laju distribusi barang dan manusia namum hal ini juga mempengaruhi ekonomi masyarakat yang dihubungkan oleh jalan tol tersebut. 


\section{PEMBAHASAN}

Pembangunan jalan tol Medan-Tebing Tinggi merupakan salah satu proyek strategis pemerintah presiden Jokowi, pembangunan ini diharapkan akan menjadi jalan tol trans sumatera yang akan menghubungkan pulau sumatera dari sabang sampai lampung. alam pembangunannya, jalan tol ini terbagi dalam dua seksi, yaitu Seksi I (Medan-PerbarakanKualanamu) sepanjang 17,80 km dan Seksi II (Perbarakan-Tebing Tinggi) sepanjang $44 \mathrm{~km}$. Jalan tol ini memiliki $2 \times 2$ lajur pada tahap awal dan $2 \times 3$ lajur pada tahap akhir dengan kecepatan rencana $100 \mathrm{~km} / \mathrm{jam}$. Peletakan batu pertama tanda dimulainya konstruksi dilaksanakan pada 23 September 2014.

Pasar bengkel merupakan salah satu nadi perekonomian dari masyarakat kabupaten Serdang Bedagai, pasar bengkel sudah ada sejak tahun 1970an dimana letak pasar bengkel ini berada di sekitaran ajalan lintas sumatera. Pasar bengkel menjadi primadona persinggahan untuk istirahat baik itu makan dan minum bagi pengendara yang berasal dari kota Medan sekitarnya yang ingin pergi ke arah sumatera bagian timur atau sebaliknya.

Dampak pembangunan jalan tol Medan- Tebing Tinggi sangat terasa bagi masayarakat UMKM yang ada di sekitaran pasar bengkel. Dampak itu bukan hanya terkena pada masyarakat namun pemerintah daerah juga, dampak pembangunan jalan tol ini terbagi dalam :

1. Pendapatan per kapita dari UMKM pasar bengkel yang menurun drastis sampai $50 \%$ pendapatan per bulan.

2. Tenaga kerja yang dipekerjakan oleh pihak UMKM yang semakin sedikit, dimana tadinya bias mempekerjakan 2 sampai 5 orang per toko maka sekarang hanya mampu mepekerjakan 1 sampai 2 orang saja.

3. Pendapatan Asli Daerah yang berasal dari restribusi, terjadi penurun signifikan sejak dibangunnya jalan tol.

4. Seedangkan dampak positif yang dirasakan oleh masayarakat pasar bengkel yaitu tidak terjadinya kemacetan dan polusi udara yang berkurang.

\section{REKOMENDASI DAN KEBIJAKAN}

\section{Rekomendasi}

Berdasarkan hasil penelitian dan fakta dilapangan yang sesuai dengan tujuan penelitian ini, maka rekomendasi hasil penelitian ini antara lain :

1. Dampak yang dihasilkan oleh pembangunan jalan tol Medan-Tebing Tingi sangat terasa pada Usaha Mikro, Kecil dan Menengah Pasar Bengkel.

2. Faktor-faktor yang dialami oleh Usaha Mikro, Kecil dan Menengah pasar bengkel adalah Faktor Kurangnya pendapatan, faktor tenaga kerja yang tidak ada lagi, faktor pendapatran daerah yang semakin menurun

\section{Kebijakan}

Bedasarkan hasil dan interpretasi penelitian ini, maka peneliti memberikan saran sebagai rekomendasi kebijakan antara lain :

1. Setiap pembangunan infrastruktur itu harus melihat aspek apa saja yang akan berdampak kepada masnyarakat lokal atau sekitar.

2. Usaha Mikro, Kecil dan Menengah sangat penting bagi pertumbuhan ekonomi dan menjaga tersedianya lapangan pekerjaan. 


\section{DAFTAR PUSTAKA}

Purwaningsih, E. Huda, N. Muslik, H. Annisariza, N. 2018. UMKM Aspek Hukum dan Manajemen Pemasaran Produk. Empatdua. Malang.

Setiawan. A. Walujodjati. A. Farida. I. 2014. Analisis Manajemen Resiko pada Proyek Pembangunan jalan tol Cisumdawu (studi kasus: development of cileumnyi-Sumedang Dawuan Toll Road Phase I). Jurnal stt garut. Vol. 11 No.1.1-10.

Sofyan. S. 2017. Peran UMKM dalam Perekonomian Indoensia. Bilancia. Vol 11 No.133-63.

Sinulingga, S. 2011. Metode Penelitian. USU Press. Medan.

Situmorang. D., M. Ayustia. R. 2019. Model Pembangunan Daerah 3T (studi kasus daerah perbatasan kabupaten Bengkayang). MBIA. Vol. 18 No. 1. 49-64.

Sugiyono. 2016. Metode Penelitian Kuantitatif, kualitatif dan R\&D.Alfabeta. Bandung.

Supriyanto. 2006. Pemberdayaan Usaha Mikro, Kecil, dan Menengah (UMKM) sebagai salah satu upaya penanggulangan kemiskinan) Jurnal Ekonomi \& Pendidikan. Vol. 3 No. 1. 1-16.

Sudirata, E., L., P., I. Kirya., K., I. Cipta., W., I. 2014. Analisis Faktor-faktor yang mempengaruhi kinerja usaha mikro kecil dan menengah (UMKM) di Kabupten Bangli. Jorunal Bisma. Vol. 2

Sedarmayanti, Syarfudin. 2011. Metodologi Penelitian. Mandar Maju. Bandung.

Tambunan, T. 2012. Usaha Mikro Kecil dan Menengah di Indonesia. LP3ES. Jakarta Undang- Undang Nomor 20 Tahun 2008 tentang Usaha Mikro, Kecil dan Menengah (UMKM):

Undang - Undang Nomor 33 Tahun 2004 Pasal 1, ayat 18 tentang Pendapatan Asli daerah

Sofyan. S,. 2017. Peran UMKM (Usaha Mikro, Kecil, dan Menengah) Dalam Perekonomian Indonesia. Bilancia, Vol. 11 No. 1, 33-64.

Wanita. N.2015. Perkembangan Usaha Mikro, Kecil dan Menengah (UMKM) di Pasar Manonda Palu. Istiqra. Vol. 3 No. 2. 250-275. 